\title{
The Anisakis simplex complex off the South Shetland Islands (Antarctica): endemic populations versus introduction through migratory hosts
}

\author{
Sven Klimpel ${ }^{1, *}$, Markus W. Busch ${ }^{2}$, Thomas Kuhn ${ }^{1}$, Anika Rohde ${ }^{2}$, Harry W. Palm ${ }^{2}$ \\ ${ }^{1}$ Biodiversity and Climate Research Centre (BiK-F), Johann Wolfgang Goethe-University, Georg-Voigt-Str. 14-16, \\ 60325 Frankfurt am Main, Germany \\ ${ }^{2}$ Institute of Zoomorphology, Cell Biology and Parasitology, Heinrich-Heine-University Düsseldorf, Universitätsstr. 1, \\ 40225 Düsseldorf, Germany
}

\begin{abstract}
Third-stage larvae (L3) of 2 Anisakis nematode species, A. simplex $\mathrm{C}$ and A. pegreffii (both A. simplex sibling species complex), were isolated from migrating myctophids around the South Shetland Islands. Gymnoscopelus nicholsi were parasitized by both nematode species, at a prevalence of $22.7 \%$ for $A$. simplex $\mathrm{C}$ and $4.0 \%$ for A. pegreffii, while Electrona carlsbergi harbored A. simplex $\mathrm{C}$ at a prevalence of $9.1 \%$. The ITS-1, $5.8 \mathrm{~S}$, and ITS-2 regions of the nematodes were identical to specimens from Pacific Canada or California (A. simplex $\mathrm{C}$ ) and the coast of China (A. pegreffii), confirming an extensive range of distribution for both species. The occurrence in migrating myctophids coupled with rare findings from other teleosts leads to the conclusion that both species were introduced from outside the Antarctic. Consequently, they are at their most southern range in the Southern Ocean, and an earlier molecular record of A. simplex $\mathrm{C}$ from the elephant seal Mirounga leonina may have detected an accidental case of infection. Delphinids, which frequently occur along South America but not in the Southern Ocean, are suggested as being the typical final hosts in the life cycles of A. simplex C and $A$. pegreffii. The myctophids had only few prey items within their stomachs, dominated by euphausiids, including Euphausia superba and planktonic copepods. These are common intermediate hosts for anisakid nematodes and are an important component of the Antarctic food web. Regular introduction events through migrating whales and myctophids are considered responsible for the occurrence of Anisakis infection in the high Antarctic.
\end{abstract}

KEY WORDS: Anisakis simplex C · Anisakis pegreffii · South Shetland Islands · Southern Ocean (Antarctica) · Myctophids · Sibling species · Zoogeography

Resale or republication not permitted without written consent of the publisher

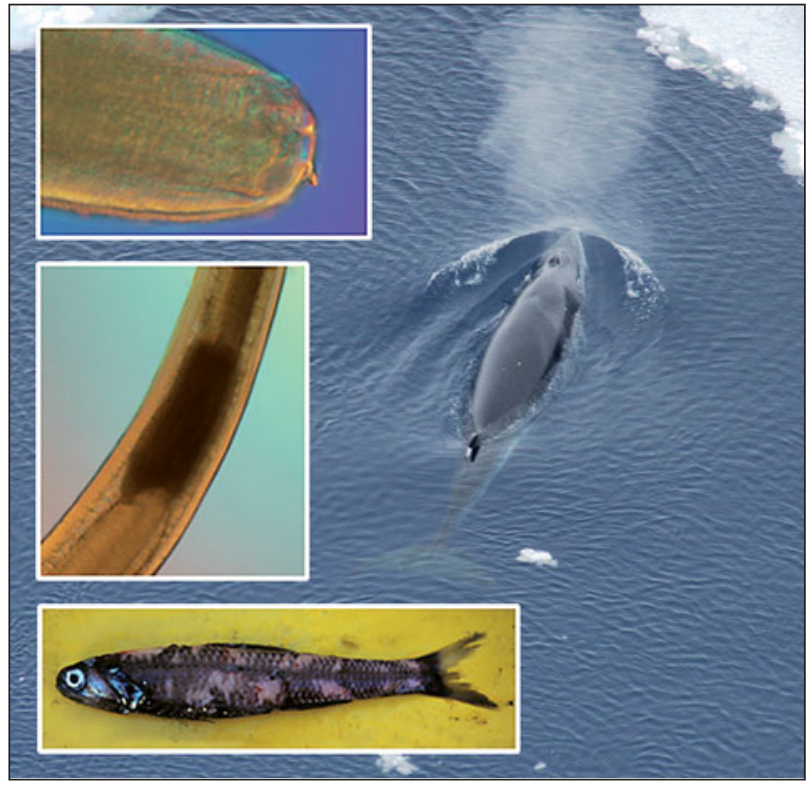

Anisakis larva with boring tooth, larva with ventricle, the migrating myctophid Gymnoscopelus nicholsi as intermediate host, and minke whale as potential final host.

Photos: Harry W. Palm (Anisakis larvae), Karl-Hermann Kock (fish), Sven Klimpel (whale)

\section{INTRODUCTION}

Antarctica (including the surrounding Southern Ocean) offers a unique natural laboratory to study the relationships of the evolutionary processes and species adaptation to extreme climate and environmental conditions (Clarke et al. 2007). The low water temperatures, the missing coastal zone due to the shelf-ice 
cover, and the drifting icebergs that regularly strand and affect the benthic communities, are some of the unique features that necessitate special adaptations of the flora and fauna. Another unique characteristic is the missing strict separation between the continental shelf and the deep sea, enabling deep-sea species to also occur in shallower waters, and especially benthodemersal shallow water species to extend their range into the deep sea.

A species-rich but well hidden component of the Antarctic fauna, fish parasites have been studied since the $19^{\text {th }}$ century, with early comprehensive studies such as by Fuhrmann (1921) or Johnston (1937). Most studies have focused on descriptions of new species and the faunistic composition of parasitic helminths (e.g. Digenea: Zdzitowiecki 1991, 1997; Cestoda: Rocka 2006; Nematoda: Klöser et al. 1992, Palm et al. 1994; Acanthocephala: Zdzitowiecki 1996). Although they are highly abundant in most studied fish species, the species richness of parasitic nematodes in the Southern Ocean seems to be limited in comparison to other parasite groups. Only few nematodes of unknown life cycles such as Ascarophis and Paranisakiopsis mature in Antarctic fish. More represented are genera that utilize fish as second intermediate/paratenic hosts and birds/ pinnipeds as final hosts, such as Contracaecum and Pseudoterranova (e.g. Palm 1999, Rocka 2004, 2006).

Most Antarctic fish belong to the perciform suborder Notothenioidei, especially the families Nototheniidae and Channichthyidae. Both have been the focus of investigations (e.g. distribution, growth, parasite fauna) and represent the most diverse and abundant fish taxa along the Antarctic coast and continental shelf (e.g. Zdzitowiecki 1991, 1997). A minor part of the known fish species in the Southern Ocean, including endemic and migrating myctophids, live in the meso- and bathypelagic zone. Especially species of the genera Electrona and Gymnoscopelus occur on the outer shelf, but they reach their maximum abundance in terms of biomass and diversity in the pelagic ecosystem. Besides consuming the krill Euphausia superba, Myctophidae play a significant role as consumers of zooplankton and they are an important food source for predators of higher trophic levels in the Antarctic food web (e.g. Pusch et al. 2004). Parasitological studies of fish species from the Antarctic continental slope and the deep sea are scarce (e.g. Walter et al. 2002, Palm et al. 2007). Rocka (2006) summarized the available information on the life cycle biology, specificity, and geographical distribution of the Digenea, Cestoda, Nematoda, and Acanthocephala of Antarctic bony fishes. The author stated that almost all helminth species maturing in Antarctic bony fishes are endemic, whereas only few are cosmopolitan or bipolar. Specificity to intermediate or paratenic hosts is wide for the majority of Antarctic helminths, while that for the final host is often narrower (Rocka 2006).

The life cycles of nematodes parasitizing marine mammals differ in the use of pelagic or benthic invertebrates (mainly crustaceans) as their first intermediate hosts and several fish species as the second or paratenic hosts (e.g. Palm et al. 1994, 2007, Palm 1999, Klimpel et al. 2008b). Initial studies on the life cycle biology of anisakid nematodes in the Weddell Sea identified a pelagic life cycle for Contracaecum radiatum (Klöser et al. 1992, Klöser \& Plötz 1992) and a benthic cycle for C. osculatum and Pseudoterranova decipiens (Palm et al. 1994, Palm 1999). Since these nematodes colonised the Antarctic environment (after establishment of the Antarctic Circumpolar Current [ACC] about 25 to 22 million years ago), they have largely maintained a similar life cycle biology to that of their relatives from non-Antarctic waters such as in the North Atlantic. Another marine nematode, the whaleworm Anisakis spp., is rare in the high Antarctic, although this genus is common in tropical and boreal regions and also in the deep sea (e.g. Klimpel et al. 2006, 2008b, Mattiucci \& Nascetti 2008, Rokicki et al. 2009).

Recent molecular studies identified distinct anisakid species within the Antarctic that were morphologically very similar to but genetically different from their nonAntarctic counterparts. To date, the sibling species Pseudoterranova decipiens E, Contracaecum osculatum D, and C. osculatum E (e.g. Zhu et al. 2002, Mattiucci \& Nascetti 2008) have been reported from this region. The record of Anisakis simplex $\mathrm{C}$ from the subAntarctic (Mattiucci \& Nascetti 2008), Anisakis sp. on the sub-Antarctic islands (e.g. Rocka 2004, 2006, Brickle et al. 2005), and the high abundance of whales led to the assumption that this genus also occurs in the Antarctic. However, a series of parasitological studies of notothenioid fish could either not detect this parasite or found it with extremely low infestation rates (e.g. Palm et al. 1998, 2007, Zdzitowiecki \& Laskowski 2004). In contrast, Rokicki et al. (2009) recorded unidentified Anisakis sp. from the same fish species with higher infestation rates.

During our investigation of 3 myctophid fish species (Electrona antarctica, E. carlsbergi, Gymnoscopelus nicholsi) off the South Shetland Islands, we were able to isolate and genetically identify Anisakis sibling species. Here we compared these nematodes to specimens from other regions in order to understand this unusual restricted occurrence in myctophid fish and its means of transmission. Possible reasons for the rareness of Anisakis sibling species in most Antarctic fish that have been studied thus far are discussed. We used the endemic $E$. antarctica and the migrating, non-endemic E. carlsbergi and G. nicholsi because they play an important role in the Antarctic food web. 


\section{MATERIALS AND METHODS}

Sample collection. Fish were sampled in December 2006 on board the German RV 'Polarstern' (research cruise ANT XXIII/8) during the field phase of the international project 'Convention for the Conservation of Antarctic Marine Living Resources' (CCAMLR) to Elephant Island (South Shetland Islands). Sampling was conducted with a bottom trawl at a trawling speed between 3.3 and 4.1 knots and a towing time of $30 \mathrm{~min}$. In total, 75 specimens of Gymnoscopelus nicholsi were captured at Stn 637 (position $61^{\circ} 5.67^{\prime}$ to $61^{\circ} 5.92^{\prime} \mathrm{S}$, $56^{\circ} 10.00^{\prime}$ to $56^{\circ} 6.43^{\prime} \mathrm{W}^{\prime}$ trawling depth range 425 to $357 \mathrm{~m}$, mean depth $391 \mathrm{~m}$; Fig. 1, AI-2), 50 specimens of Electrona antarctica at Stn $616\left(60^{\circ} 49.81^{\prime}\right.$ to $60^{\circ} 49.20^{\prime} \mathrm{S}, 55^{\circ} 36.76^{\prime}$ to $55^{\circ} 40.27^{\prime} \mathrm{W}_{\text {; }}$ trawling depth range 483 to $486 \mathrm{~m}$, mean depth $484 \mathrm{~m}$ ), and 55 specimens of E. carlsbergi at Stn $622\left(60^{\circ} 56.70^{\prime}\right.$ to $60^{\circ} 55.93^{\prime} \mathrm{S}$, $55^{\circ} 52.71^{\prime}$ to $55^{\circ} 50.79^{\prime} \mathrm{W}_{\text {; }}$ trawling depth range 218 to 307 m, mean depth 262 mi Fig. 1, AI-1; all Family Myctophidae) in order to study their metazoan parasites and stomach contents. All fish were deep frozen at $-40^{\circ} \mathrm{C}$ immediately after capture for subsequent examination. In the ship's laboratory, the standard length ( $\mathrm{SL}$, to the nearest $0.1 \mathrm{~cm}$ ) and total weight (TW, to the nearest $0.1 \mathrm{~g}$ ) were determined (Table 1). Prior to examination, each specimen was defrosted at 0 to $1^{\circ} \mathrm{C}$. Fish were identified in accordance with Gon \& Heemstra (1990).

Stomach content analyses. The stomach contents were sorted, and prey items were identified to the lowest possible taxon and grouped into taxonomic categories. To determine the relative importance of food items, the numerical percentage of prey $(\mathrm{N} \%)$, the weight percentage of prey $(\mathrm{W} \%)$, and the frequency of occurrence $(\mathrm{F} \%)$ were determined (Hyslop 1980, Amundsen et al. 1996). Using these 3 indices, an index of relative importance (IRI; Pinkas et al. 1971) was calculated. The importance of a specific prey item increases with higher values for N, W, F, and IRI.

Parasitological examination. The presence of anisakid nematodes was determined for all organs using a stereomicroscope. The body cavity was opened to microscopically examine the liver, stomach, pyloric caeca, intestine, and gonads for nematodes, and the stomach contents were removed. The specimens were freed from host tissue and morphologically identified using existing keys and descriptions. After removal from the host tissue, Anisakis spp. larvae were stored in absolute $(\sim 100.0 \%)$ ethanol for further molecular identification (see below). The ecological and parasitological terminology follows Bush et al. (1997): preva-

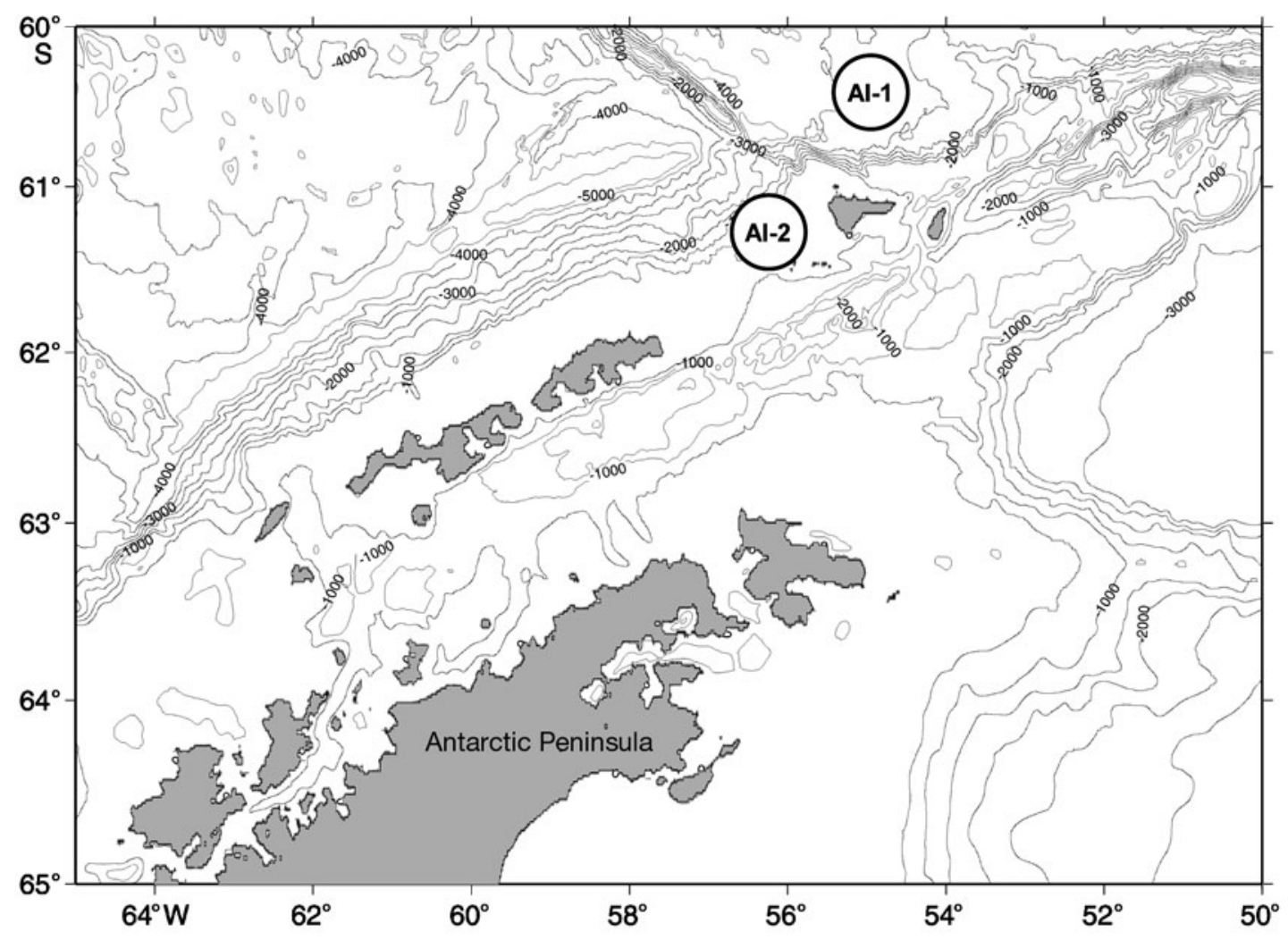

Fig. 1. Areas of investigation. AI-1: area of investigation 1, Electrona antarctica and E. carlsbergi; AI-2: area of investigation 2, Gymnoscopelus nicholsi 
Table 1. Number, lengths, weights, food items, and parasites of the studied fish species. F\%: frequency of occurrence, $\mathrm{N} \%$ : numerical percentage of prey, W\%: weight percentage of prey, IRI: index of relative importance; $\mathrm{P} \%$ : prevalence; I: intensity; mI: mean intensity; A: mean abundance. See 'Materials and methods' for definitions of terms

\begin{tabular}{|c|c|c|c|c|c|c|c|c|c|c|c|c|}
\hline Fish species & \multicolumn{4}{|c|}{ Gymnoscopelus nicholsi $(\mathrm{n}=75)$} & \multicolumn{4}{|c|}{ Electrona carlsbergi $(\mathrm{n}=55)$} & \multicolumn{4}{|c|}{ Electrona antarctica $(\mathrm{n}=50)$} \\
\hline Measurements & \multicolumn{2}{|c|}{ Range } & \multicolumn{2}{|c|}{ Mean } & \multicolumn{2}{|c|}{ Range } & \multicolumn{2}{|c|}{ Mean } & \multicolumn{2}{|c|}{ Range } & \multicolumn{2}{|c|}{ Mean } \\
\hline Standard length $(\mathrm{cm})$ & \multirow{2}{*}{\multicolumn{2}{|c|}{$\begin{array}{l}13.2-15.9 \\
20.9-39.5\end{array}$}} & \multirow{2}{*}{\multicolumn{2}{|c|}{$\begin{array}{l}14.8 \\
29.8\end{array}$}} & \multicolumn{2}{|c|}{$6.1-9.3$} & \multicolumn{2}{|c|}{7.7} & \multicolumn{2}{|c|}{$6.8-10.1$} & \multicolumn{2}{|c|}{8.5} \\
\hline Total weight (g) & & & & & & -7.9 & 5 & .9 & 3.8 & 17.0 & 8. & \\
\hline Prey items & $\mathrm{F} \%$ & $\mathrm{~N} \%$ & $\mathrm{~W} \%$ & IRI & $\mathrm{F} \%$ & $\mathrm{~N} \%$ & $\mathrm{~W} \%$ & IRI & $\mathrm{F} \%$ & $\mathrm{~N} \%$ & $\mathrm{~W} \%$ & IRI \\
\hline Copepoda undet. & 72.5 & 54.7 & 2.0 & 4110.7 & 37.5 & 42.1 & 1.2 & 1623.7 & 11.1 & 17.4 & 0.5 & 198.7 \\
\hline Euphausia superba & 3.9 & 4.3 & 27.3 & 123.2 & 62.5 & 36.3 & 85.7 & 7625.0 & 55.6 & 47.8 & 92.6 & 7806.2 \\
\hline Euphausia spp. & 54.9 & 29.5 & 69.6 & 5440.1 & 27.5 & 18.6 & 11.9 & 838.7 & 33.3 & 30.5 & 1.7 & 1072.3 \\
\hline Gammaridae & & & & & 2.5 & 1.0 & 0.3 & 3.3 & & & & \\
\hline Ostracoda undet. & 9.8 & 3.6 & 0.1 & 36.3 & 2.5 & 1.0 & 0.1 & 2.7 & & & & \\
\hline Crustacea undet. & 11.8 & 4.3 & 0.4 & 55.5 & & & & & & & & \\
\hline Gastropoda & & & & & 2.5 & 1.0 & 0.8 & 4.5 & 5.6 & 4.3 & 5.2 & 53.2 \\
\hline Teleostei undet. & 9.8 & 3.6 & 0.5 & 40.1 & & & & & & & & \\
\hline Parasites & $\mathrm{P} \%$ & I & $\mathrm{mI}$ & A & $\mathrm{P} \%$ & I & $\mathrm{mI}$ & $\mathrm{A}$ & $\mathrm{P} \%$ & I & $\mathrm{mI}$ & A \\
\hline Anisakis simplex C & 22.7 & $1-4$ & 1.4 & 0.31 & 9.1 & 1 & 1.0 & 0.09 & & & & \\
\hline Anisakis pegreffii & 4.0 & 1 & 1.0 & 0.04 & & & & & & & & \\
\hline
\end{tabular}

lence $(\mathrm{P})$ is the number of infected fish with 1 or more individuals of a particular parasite species (or taxonomic group) divided by the number of hosts examined (expressed as a percentage). Intensity (of infection, I) is the number of individuals of a particular parasite species in a single infected host (expressed as a numerical range). Mean intensity (of infection, $\mathrm{mI}$ ) is the average intensity; in other words, it is the total number of parasites of a particular species found in a sample divided by the number of infected hosts. Mean abundance (A) is the total number of individuals of a particular parasite species in a sample of a particular host species divided by the total number of hosts of that species examined, including both infected and uninfected hosts. Furthermore, we used the following terms and definitions: final host - host in which a parasite reaches sexual maturity; intermediate host - required by a parasite to complete its life cycle (usually the host in which it undergoes considerable morphological or physiological change); paratenic host - not required by a parasite to complete its life cycle, and no detectable morphological change occurs within this host.

PCR amplification and sequencing of ITS-1, 5.8S, and ITS-2. Genomic DNA was isolated and purified from individual Anisakis spp. larvae using a genomic DNA extraction kit (Peqlab Biotechnology) according to the instructions of the manufacturer. The rDNA region comprising the internal transcribed spacer ITS-1, 5.8S, ITS-2, and flanking sequences (=ITS+) was amplified using the previously described primers NC5 (5'-GTA GGT GAA CCT GCG GAA GGA TCA TT-3') and NC2 (5'-TTA GTT TCT TTT CCT CCG CT-3') (Zhu et al. 2000). The PCR reaction $(26 \mu l)$ included $13 \mu \mathrm{l}$ of Master-Mix (Peqlab Biotechnology) containing dNTPs, $\mathrm{MgCl}_{2}$, buffer, and Taq polymerase, $3 \mu \mathrm{l}$ of each primer, $2 \mu$ l of distilled Water, and $5 \mu$ l of genomic DNA. Each PCR reaction was performed in a thermocycler (Biometra) under the following conditions: after initial denaturation at $95^{\circ} \mathrm{C}$ for $15 \mathrm{~min}, 30$ cycles of $94^{\circ} \mathrm{C}$ for $1 \mathrm{~min}$ (denaturation), $55^{\circ} \mathrm{C}$ for $1 \mathrm{~min}$ (annealing), and $72^{\circ} \mathrm{C}$ for $1 \mathrm{~min}$ (extension), followed by a final extension at $72^{\circ} \mathrm{C}$ for $5 \mathrm{~min}$. Samples without DNA were included in each PCR run. PCR products were examined on $1 \%$ agarose gels. A 100 bp ladder marker (peqGOLD) was used to estimate the size of the PCR products. To identify the anisakid nematodes, the PCR products were purified with an E.Z.N.A. Cycle-Pure Kit (Peqlab Biotechnology). Afterwards, a total volume of $7 \mu \mathrm{l}$, including $2 \mu \mathrm{l}$ of primer (individually) and $5 \mu \mathrm{l}$ of the PCR product (250 ng $\mathrm{ul}^{-1}$ ) were sequenced by Seqlab (Göttingen, Germany). Both spacers and the 5.8S gene from each PCR product were sequenced in both directions, using primers NC5, NC13 (forward; 5'-ATC GAT GAA GAA CGC AGC-3'), NC13R (reverse; 5'-GCT GCG TTC TTC ATC GAT-3'), XZ1R (reverse; 5'-GGA ATG AAC CCG ATG GCG CAA T-3'), and NC2. The obtained sequences were identified via GenBank and aligned with previously characterized sequences of anisakid nematodes, using CLUSTAL W (1.83) Multiple Sequence Alignments (Thompson et al. 1994). Among the observed Anisakis siblings, the nucleotide sequences of all 3 regions 
Table 2. Anisakis spp. and Hysterothylacium aduncum. GenBank accession numbers of sequences of ascaridoid nematodes used for comparative analyses (Fig. 2). F: fish host, W: whale host, S: seal host, A: adult, L: larva, s.S.: sensu stricto

\begin{tabular}{|c|c|c|c|c|c|c|}
\hline Species & Code & Host & F/W/S & $\mathrm{A} / \mathrm{L}$ & Locality & $\begin{array}{c}\text { GenBank } \\
\text { accession no. }\end{array}$ \\
\hline A. brevispiculata & Abrevflo & Kogia breviceps & W & A & Coast of Florida, USA (Atlantic Ocean) & AY826719 \\
\hline \multirow[t]{3}{*}{ A. pegreffii } & ApegMed & Micromesistius poutassou & $\mathrm{F}$ & $\mathrm{L}$ & Coast of Italy (Mediterranean Sea) & AY826720 \\
\hline & ApegChi & Seriola dumerili & $\mathrm{F}$ & $\mathrm{L}$ & Coast of China (Pacific Ocean) & EU933997 \\
\hline & ApegJap & Theragra chalcogramma & $\mathrm{F}$ & $\mathrm{L}$ & Coast of Japan (Pacific Ocean) & EU624343 \\
\hline \multirow[t]{4}{*}{ A. simplex C } & AsimCCan & Pseudorca crassidens & W & A & Coast of Canada (Pacific Ocean) & AY826722 \\
\hline & AsimCCal & Mirounga angustirostris & $\mathrm{S}$ & A & Coast of California, USA (Pacific Ocean) & AY821736 \\
\hline & AsimCAnt1 ${ }^{\mathrm{a}}$ & Gymnoscopelus nicholsi & $\mathrm{F}$ & $\mathrm{L}$ & South Shetland Islands (Antarctica) & GQ131689 \\
\hline & AsimCAnt $2^{\mathrm{a}}$ & Electrona carlsbergi & $\mathrm{F}$ & $\mathrm{L}$ & South Shetland Islands (Antarctica) & GQ167200 \\
\hline \multirow[t]{3}{*}{ A. simplex (s.s.) } & AsimssGS & Macrourus berglax & $\mathrm{F}$ & $\mathrm{L}$ & Greenland Sea (Atlantic Ocean) & GQ131690 \\
\hline & AsimssMAR & Myctophum punctatum & $\mathrm{F}$ & $\mathrm{L}$ & Mid-Atlantic Ridge (Atlantic Ocean) & GQ131691 \\
\hline & AsimssJap & Theragra chalcogramma & $\mathrm{F}$ & $\mathrm{L}$ & Coast of Japan (Pacific Ocean) & EU624342 \\
\hline \multirow[t]{4}{*}{ A. typica } & AtypThai & Rastrelliger kanagurta & $\mathrm{F}$ & $\mathrm{L}$ & Coast of Thailand & AB432909 \\
\hline & AtypIndo1 & Auxis rochei rochei & $\mathrm{F}$ & $\mathrm{L}$ & Coast of Indonesia (Indian Ocean) & EU346091 \\
\hline & AtypIndo2 & Auxis rochei rochei & $\mathrm{F}$ & $\mathrm{L}$ & Coast of Indonesia (Indian Ocean) & EU346093 \\
\hline & AtypBra & Stenella longirostris & W & A & Coast of Brazil (Atlantic Ocean) & AY826724 \\
\hline A. ziphidarum & AzipSA & Ziphius cavirostris & W & A & Coast of South Africa & AY826725 \\
\hline A. typica & AtypIndo & Auxis rochei rochei & $\mathrm{F}$ & $\mathrm{L}$ & Coast of Indonesia (Indian Ocean) & EU346092 \\
\hline H. aduncum & HaduRef & Zoarces viviparus & $\mathrm{F}$ & $\mathrm{L}$ & Gdansk Bay (Baltic Sea) & AJ937673 \\
\hline
\end{tabular}

(ITS-1, 5.8S, ITS-2) were compared. Resulting sequence data of anisakid siblings were compared to previously published sequence data in GenBank to analyze intraspecific differences among the specimens (Table 2). The accession numbers of $A$. pegreffii (from Gymnoscopelus nicholsi), A. simplex C (G. nicholsi), and A. simplex C (Electrona carlsbergi) are GQ131688, GQ131689, and GQ167200, respectively.

Our sequences of Anisakis simplex C and A. pegreffii were compared to selected sequences in GenBank (Table 2) to create a distance table using Dnadist (PHYLIP Version 3.67, Kimura-2-parameter; Appendix 1). A sequence of the rDNA ITS-1, 5.8S, and ITS-2 of Hysterothylacium aduncum from eelpout Zoarces viviparus, previously deposited in GenBank (AJ937673), was included as an outgroup to root the Anisakis phylogenetic tree. The maximum likelihood tree was built using Seqboot (bootstrap, 1000 replicates), Phyml (Guindon \& Gascuel 2003), and Consense (PHYLIP Version 3.67). The optimal model for maximum likelihood was assessed using the Akaike Information Criterion (AIC) as implemented in the online tool Findmodel (Leitner et al. 2005). This analysis supported the HKY plus Gamma model (Hasegawa et al. 1985) as the best fit substitution model for the data. We ran maximum likelihood using 4 gamma categories.

\section{RESULTS}

\section{Fish stomach contents}

The 75 specimens of Gymnoscopelus nicholsi had a mean SL of $14.8 \mathrm{~cm}$ (range 13.2 to $15.9 \mathrm{~cm}$ ) and a mean TW of $29.8 \mathrm{~g}$ (range 20.9 to $39.5 \mathrm{~g}$ ). The prey items were of pelagic origin or associated with the benthopelagic (diurnal vertical migrations) environment. All of the identifiable prey items were small crustaceans and fish, mainly in an advanced stage of digestion. The stomachs contained calanoid copepods ( $\mathrm{F}=$ $72.5 \%)$, Euphausia superba $(\mathrm{F}=3.9 \%)$, Euphausia spp. $(\mathrm{F}=54.9 \%)$, ostracods $(\mathrm{F}=9.8 \%)$, and undetermined crustaceans $(F=11.8 \%)$ and teleosts $(F=9.8 \%)$. Sorted by quantity and weight percentage, Euphausia spp. ( $\mathrm{N}$ $=29.5 \%, \mathrm{~W}=69.6 \%$ ) were followed by calanoid copepods $(\mathrm{N}=54.7 \%, \mathrm{~W}=2.0 \%)$ and E. superba $(\mathrm{N}=4.3 \%$, $\mathrm{W}=27.3 \%)$. The IRI was highest for Euphausia spp. (5440.1), calanoid copepods (4110.7), and E. superba (123.2; Table 1).

Both Electrona species were smaller, with a mean SL of $8.5 \mathrm{~cm}$ (range 6.8 to $10.1 \mathrm{~cm}$ ) for E. antarctica and $7.7 \mathrm{~cm}$ (range 6.1 to $9.3 \mathrm{~cm}$ ) for E. carlsbergi, with a mean TW of $8.5 \mathrm{~g}$ (range 3.8 to $17.0 \mathrm{~g}$ ) and $5.9 \mathrm{~g}$ (range 4.3 to $7.9 \mathrm{~g}$ ), respectively. Most prey items of both fish 
were pelagic crustaceans, mainly calanoid copepods and the euphausiid Euphausia superba. Ostracods, gammariids, and gastropods were minor components. E. superba was numerically predominant $(\mathrm{N}=47.8$ and $36.3 \%$ for E. antarctica and E. carlsbergi, respectively, followed by Euphausia spp. and calanoid copepods with values of 30.5 and $17.4 \%$ as well as 18.6 and $42.1 \%$, respectively. The frequencies of occurrence (F\%) of E. superba in both fish species were similar: 55.6 and $62.5 \%$, respectively. Values of W (\%) for $E$. superba and for undetermined Gastropoda for $E$. antarctica were 92.6 and $5.2 \%$, with values of $85.7 \%$ for E. superba and $11.9 \%$ for Euphausia spp. in E. carlsbergi stomachs. For both fish species, the IRI was highest for E. superba, followed by Euphausia spp. and calanoid copepods (Table 1).

\section{Genetic identification}

The ITS-1, 5.8S, and ITS-2 sequences were determined for 25 Anisakis nematodes that were isolated from the 20 infected Gymnoscopelus nicholsi and from the 5 infected Electrona carlsbergi. The sequence analyses of the nematodes from the South Shetland Islands revealed 2 sibling species, Anisakis simplex $\mathrm{C}$ ( $\mathrm{n}=17$ ) and $A$. pegreffii $(\mathrm{n}=3)$. In E. carlsbergi only $A$. simplex $C(\mathrm{n}=5)$ was identified. The lengths of the PCR product including the 3 regions ITS-1, 5.8S, and ITS-2 with flanking sequences ranged from 895 to $959 \mathrm{bp}$ for A. simplex C and 919 to $959 \mathrm{bp}$ for A. pegreffii. The length of the ITS-1 and ITS-2 sequences of A. simplex C ranged from 376 to 392 and 300 to $314 \mathrm{bp}$. The 5.8S sequences were all 157 bp long. The $\mathrm{G}+\mathrm{C}$ contents were $45.5-47.2 \%$ (ITS-1), 51.0-52.3\% (5.8S), and $42.4-43.9 \%$ (ITS-2). The length of the ITS-1 and ITS-2 sequences of $A$. pegreffii were 390-391 and 305-311 bp. The length of the 5.8S sequence of all samples was $157 \mathrm{bp}$. The $\mathrm{G}+\mathrm{C}$ contents were $46.7-47.1 \%$ (ITS-1), 51.6\% (5.8S), and 42.0-42.6\% (ITS-2).

The sequence of Anisakis simplex C from Gymnoscopelus nicholsi (GQ131689) was identical to a sequence from Canada (AY26722), while the sequence of A. simplex C from Electrona carlsbergi (GQ167200) corresponded closely (99.0\%) with a sequence from the coast of California (AY821736). Both sequences differed in only 2 positions. An alignment of the A. simplex C sequences from G. nicholsi and E. carlsbergi differed in 2 positions, 1 in the ITS-1 and 1 in the ITS- 2 region. A. pegreffii from G. nicholsi (GQ131688) was identical $(100.0 \%)$ to the sequence EU933997 of $A$. pegreffii from China (Fig. 2).

\section{Anisakis spp. composition}

Gymnoscopelus nicholsi was parasitized by 2 different anisakid nematodes, viz. third-stage larvae (L3) of A. simplex $\mathrm{C}$ and $A$. pegreffii (molecular identification above). Both species are members of the A. simplex complex (Fig. 3). They were isolated from the organs of the body cavity with a prevalence of $22.7 \%$ and a mean intensity of 1.4 for $A$. simplex $\mathrm{C}$ and $4.0 \%$ and a mean intensity of 1.0 for $A$. pegreffii. The anisakid parasite fauna of both analyzed Electrona species was different. The nematode species A. simplex $C$ was recorded and genetically identified only for $E$. carlsbergi with a prevalence of $9.1 \%$, while E. antarctica were Anisakis free. The third-stage larvae were encapsulated on the organs of the body cavity of the former (Table 1).

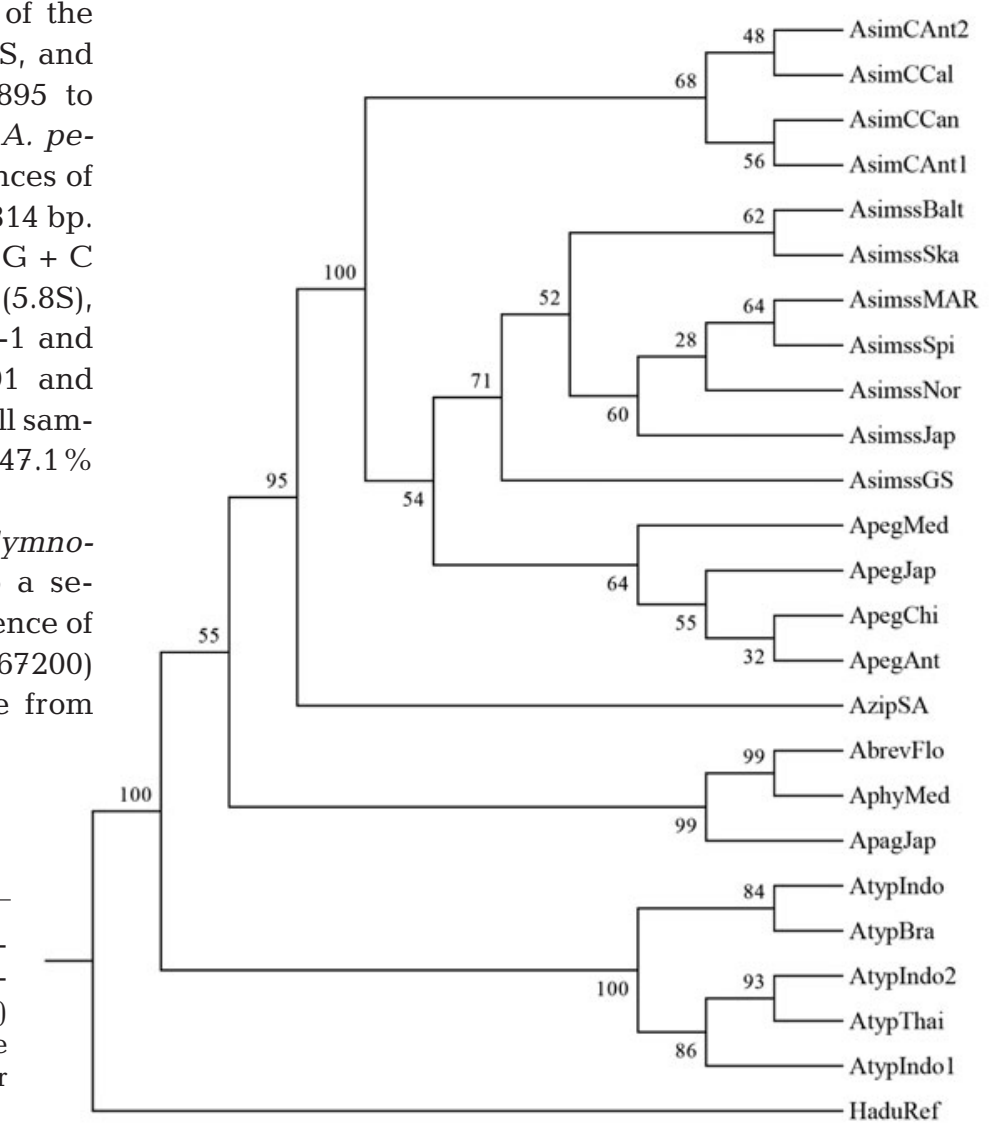

Fig. 2. Anisakis spp. Consensus phylogenetic tree resulting from maximum likelihood analysis for ITS1/5.8S/ITS-2 regions of 25 sequences. Probabilities (\%) are given for internal branches. Specimen codes are listed in Table 2. Bootstrap values were calculated over 1000 replicates 


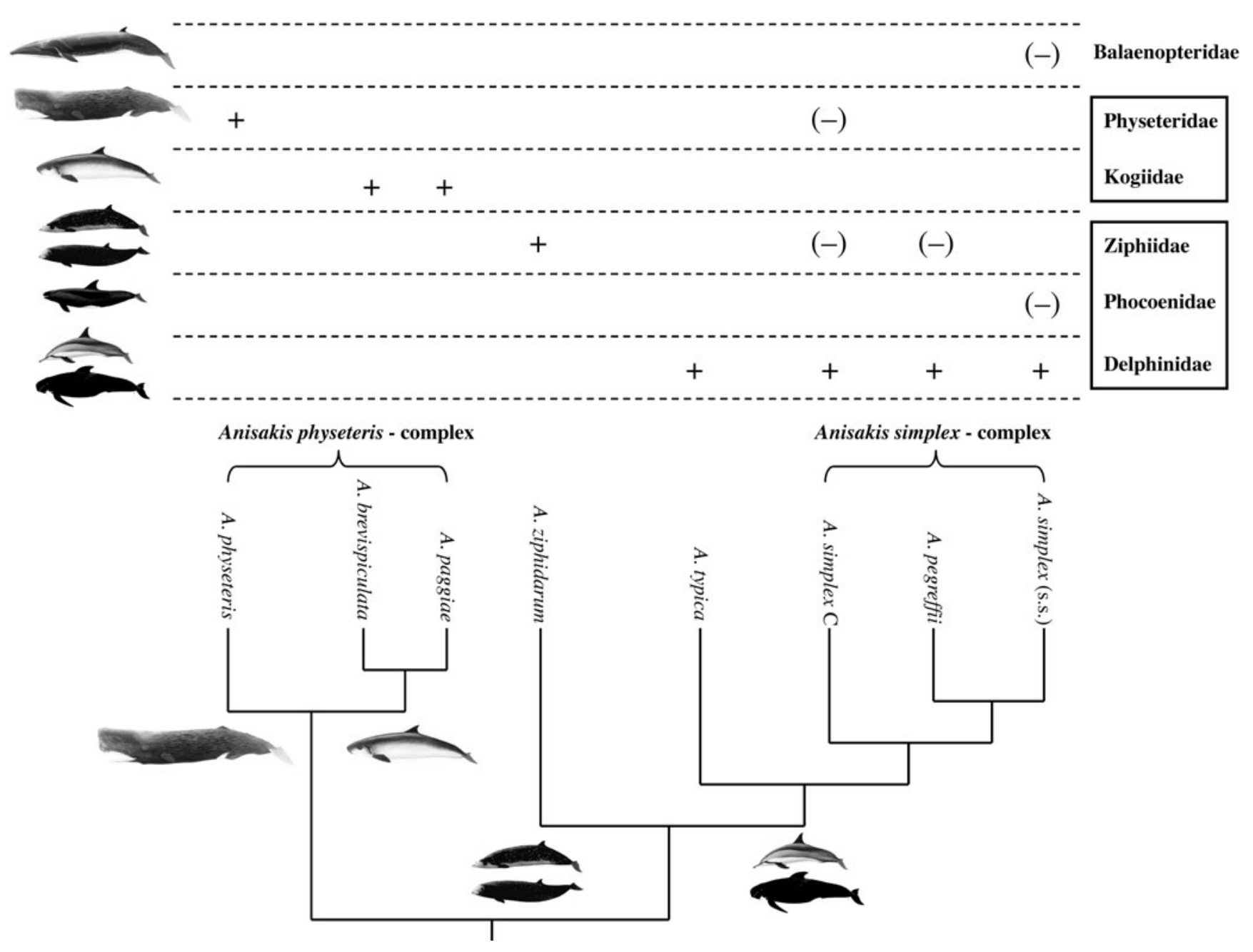

Fig. 3. Anisakis spp. Final host distribution in the A. physeteris and A. simplex complexes. Note that A. physeteris, A. brevispiculata, and A. paggiae are typical for the cetacean families Physeteridae and Kogiidae, while the A. simplex complex together with A. typica is most common in the Delphinidae (typical hosts: +). Regular records in other cetacean families are interpreted as secondary (additional) final host infections (accidental: -). Bold squares indicate related cetacean families, according to Nikaido et al. (2001) and May-Collado \& Agnarsson (2006). Relationships of Anisakis spp. according to Mattiucci \& Nascetti (2006, 2008). s.s.: sensu stricto

\section{DISCUSSION}

Here we have, for the first time, genetically identified 2 Anisakis sibling species, A. simplex $\mathrm{C}$ and $A$. pegreffii, from 2 myctophids in the high Antarctic around the South Shetland Islands. In contrast to earlier studies (e.g. Palm et al. 2007) from the same region, both myctophids are the first teleosts that have been infected with Anisakis species at such low latitudes.

According to Rocka (2006), adult specimens of the genus Anisakis (A. similis and A. physeteris) were reported from Antarctic marine mammals in the 1940s and 1950s (Johnston \& Mawson 1945, Mozgovoy 1953). Dailey \& Vogelbein (1991) identified Anisakis species from 3 migrating whales, while Mattiucci \& Nascetti
(2007) reported A. simplex C from elephant seals Mirounga leonina. However, no other adult Anisakis have been reported from the region, and their abundance in final and intermediate hosts has not been explored. Within a series of parasitological studies of the most frequent teleosts around the South Shetland Islands and in the Weddell Sea, Palm et al. (1998: Notothenia coriiceps; 2007: Chaenocephalus aceratus, Lepidonotothen squamifrons, Trematomus eulepidotus) could not identify any Anisakis larvae in the studied fish, and even the Antarctic herring Pleuragramma antarcticum as the predominant nototheniid species in the pelagic realm was uninfected (e.g. Bartsch 1985). This contrasts the report by Rokicki et al. (2009) on the infection with morphologically identified Anisakis sp. 
of 11 different fish species, including Electrona antarctica, L. squamifrons (= L. kempi), N. coriiceps, and T. eulepidotus. In the present study 2 myctophids, Gymnoscopelus nicholsi and E. carlsbergi, were found to be infected, whereas the endemic E. antarctica was free of Anisakis.

Among the studied myctophids, Electrona antarctica lives circumpolar south of the Antarctic convergence, while E. carlsbergi and Gymnoscopelus nicholsi also reach high biomass in more northern waters up to the Patagonian shelf (e.g. Linkowski 1985, Gon \& Heemstra 1990, Brickle et al. 2009). The latter two species usually migrate into high Antarctic waters during extensive annual migrations. Both migratory myctophids were infected with Anisakis spp., while the most common Antarctic endemic myctophid as well as other abundant fish species (see above) were Anisakis-free in the area of investigation. In contrast to North Atlantic regions such as the Greenland Sea and the northern Mid-Atlantic Ridge (e.g. Klimpel et al. 2006, 2007, 2008a, Kellermanns et al. 2007), the abundance and distribution of whaleworms within different Antarctic teleosts are fairly low, especially compared to the other anisakid nematodes Pseudoterranova decipiens E and Contracaecum spp. (Klöser et al. 1992, Palm 1999). Both genera typically infect seals, whereas Anisakis is most common in cetaceans and only occasionally infects seals (e.g. Klöser et al. 1992, Palm 1999, Klimpel et al. 2004, 2008b). Crabeater seals Lobodon carcinophagus, Weddell seals Leptonychotes weddelli, and leopard seals Hydrurga leptonyx are most frequently distributed in high Antarctic waters and are the main abundant top predators (Nordøy et al. 1995, Flores et al. 2004). The elephant seal, another abundant pinniped species, has a circumpolar distribution, and its breeding colonies are mainly concentrated on and around the sub-Antarctic islands (Slade et al. 1998).

Summarizing the available studies on fish parasites in Antarctic waters, Anisakis spp. seem to be rare visitors compared to other anisakid genera. This is astonishing, since cetaceans are common in high Antarctic feeding grounds, enabling the transfer of parasites within these waters. For example, minke Balaenoptera bonaerensis and fin whales $B$. physalus, long-finned pilot whales Globicephala melas, Cuvier's beaked whales Ziphius cavirostris, and sperm whales Physeter macrocephalus occur in great numbers and biomass in sub-Antarctic and Antarctic areas north of the Antarctic peninsula and near the ice edge (e.g. Kasamatsu 2000, Williams et al. 2006). Dailey \& Vogelbein (1991) reported adult Anisakis in sei B. borealis, northern minke B. acutorostrata, and sperm whales in Antarctic commercial whaling sectors, although according to the given position data, only a single record was at $70^{\circ}$ south in high Antarctic waters. One would there- fore expect the introduction of Anisakis into Antarctic waters to occur most commonly via migrating whales and one would expect a similar high Anisakis infection rate compared to other anisakids. However, sealworms of the genera Contracaecum and Pseudoterranova clearly dominate the Antarctic anisakid nematode fauna.

Both recorded Anisakis species within the present study are known for their wide distribution outside the Southern Ocean (Mattiucci \& Nascetti 2008). Since its first identification by Mattiucci et al. (1997), A. simplex $\mathrm{C}$ has exhibited a scattered zoogeographical distribution, including the Canadian and Chilean Pacific coasts, waters around New Zealand, and Atlantic waters off South Africa (Mattiucci \& Nascetti 2008). Adults of this species have been genetically identified from cetaceans of the families Delphinidae and Ziphiidae (e.g. Klimpel et al. 2008b, Mattiucci \& Nascetti 2008; Fig. 3), and a record exists from elephant seals from the sub-Antarctic (Mattiucci \& Nascetti 2008). The ITS1-2 region of our specimens from the South Shetland Islands was identical to that of specimens from Canada or California. A. pegreffii utilizes toothed whales of the family Delphinidae as its final hosts; however, it also infects the families Ziphiidae, Physeteridae, and Neobalaenidae (Mattiucci et al. 1997; Fig. 3), mainly in the Atlantic Ocean and the Mediterranean Sea but also in Australian waters. The specimens from Gymnoscopelus nicholsi were genetically identical to specimens from China. However, both species are at their most southern distribution in the Southern Ocean.

Here we identified migrating myctophids (distributed in- and outside the Southern Ocean) as common teleost intermediate hosts for the whaleworms Anisakis spp. in sub-Antarctic waters. In contrast, the endemic Electrona antarctica as well as all benthodemersal and pelagic fish species that we studied were Anisakis free. It appears that independent of earlier records of Anisakis in Antarctica (see above), our specimens may have migrated into these waters through their myctophid hosts. A. simplex C is common along the South American coast, and A. pegreffii is very common in mid-Atlantic waters. This would suggest that the record of $A$. simplex $C$ by Mattiucci \& Nascetti (2008) represents an accidental case of infection in elephant seals. It seems that the Antarctic waters are at the southern range for both recorded Anisakis species. The studied myctophids had only few prey items within their stomachs, and these were clearly dominated by euphausiids including Euphausia superba and planktonic copepods. Especially E. superba plays an important role as a key prey item of numerous top predators and is the most common prey for pelagic myctophids in Antarctic waters (Pusch et 
al. 2004). Euphausiids and copepods are known as typical first intermediate hosts, while pelagic fish species are second or paratenic hosts in the life cycle of Anisakis species outside the Southern Ocean (e.g. Klimpel et al. 2004, 2008b). Regulation of the nematode populations off the South Shetland Islands must then be expected to take place in the first crustacean intermediate host, because a survey of more than 50000 E. superba revealed no nematode larvae (Kagei et al. 1978). If nematode populations were strictly controlled in the first intermediate host, the numbers of parasites might be too low to allow significant transmission into the fish intermediate hosts in Antarctic waters. Furthermore, Delphinidae, the typical final hosts in the life cycles of $A$. simplex $\mathrm{C}$ and $A$. pegreffii (Fig. 3) are missing in the Southern Ocean, while only some of the secondary (Fig. 3) final hosts (e.g. migrating whales of the Physeteridae and Ziphiidae) are known to occur in the Antarctic. This can explain the lower abundance of Anisakis spp. in high Antarctic waters.

\section{CONCLUSIONS}

Our study confirms that 2 Anisakis species, A. simplex $\mathrm{C}$ and $A$. pegreffii, occur in Antarctic waters. Our specimens were genetically identical to specimens recorded earlier from Pacific Canada (A. simplex $\mathrm{C}$ ) and from China (A. pegreffii), demonstrating the extensive range of their distribution. Comparison to sequences from GenBank identified this as a common pattern in other Anisakis species as well, which have a wide distribution with minor genetic changes of the ITS1-2 regions. The occurrence in migrating myctophids with rare findings from other teleosts leads to the conclusion that both Anisakis species originated outside the Antarctic in more northern waters, where delphinids serve as common final hosts. The presence of physeterids and ziphiids in Antarctic waters and the near absence of Anisakis in most endemic Antarctic fish suggests that these whaleworms are transported into the Antarctic through their migrating teleost intermediate hosts. Delphinids have been identified as the main final hosts for A. simplex C and A. pegreffii (e.g. Klimpel et al. 2008b, Mattiucci \& Nascetti 2008), while other cetaceans and elephant seals serve as secondary (additional) or erroneous hosts, respectively. Regular introduction events have likely led to the infection by Anisakis of Antarctic fish, bringing into question the existence of stable Anisakis populations. Further studies and the search for Anisakis spp. in Antarctic waters are needed to confirm these preliminary interpretations.
Acknowledgements. We thank J. H. Lott (Geodetical Institute, University of Karlsruhe) for providing the map of the area of investigation, and R. Kuchta (Institute of Parasitology, České Budějovice, Czech Republic) for providing Anisakis specimens from Spitsbergen. This study was financially supported by the German Research Council (DFG KL 2087/1-1, 1-2; PA 664/4-1, 4-2) and by Research and Innovation funds of the Heinrich-Heine-University Düsseldorf (Antarctic project).

\section{LITERATURE CITED}

Amundsen PA, Gabler HM, Staldvik FJ (1996) A new approach to graphical analysis of feeding strategy from stomach contents data-modification of the Costello (1990) method. J Fish Biol 48:607-614

Bartsch A (1985) Vergleichende Untersuchungen zum Parasitenbefall von Pleuragramma antarcticum und Trematomus scotti (Pisces: Nototheniidae) aus der östlichen und südlichen Weddell-See (Antarktis). MSc thesis, University of Bochum

Brickle P, MacKenzie K, Pike A (2005) Parasites of the Patagonian toothfish, Dissostichus eleginoides Smitt 1898, in different parts of the Subantarctic. Polar Biol 28:663-671

> Brickle P, Arkhipkin I, Laptikhovsky V, Stocks A, Taylor A (2009) Resource partitioning by two large planktivorous fishes Micromesistius australis and Macruronus magellanicus in the Southwest Atlantic. Estuar Coast Shelf Sci 84: 91-98

Bush AO, Lafferty KD, Lotz JM, Shostak AW (1997) Parasitology meets ecology on its own terms: Margolis et al. revisited. J Parasitol 83:575-583

Clarke A, Johnston NM, Murphy EJ, Rogers AD (2007) Antarctic ecology from genes to ecosystems: the impact of climate change and the importance of scale. Philos Trans R Soc Lond B Biol Sci 362:5-9

Dailey MD, Vogelbein WK (1991) Parasite fauna of three species of Antarctic whales with reference to their use as potential stock indicators. Fish Bull 89:355-365

Flores H, Kock KH, Wilhelms S, Jones CD (2004) Diet of two icefish species from the South Shetland Islands and Elephant Island, Champsocephalus gunnari and Chaenocephalus aceratus. Polar Biol 27:119-129

Fuhrmann O (1921) Die Cestoden der Deutschen SüdpolarExpedition 1901-1903. Dtsch Südpol Exped 16:469-524

Gon O, Heemstra PC (eds) (1990) Fishes of the Southern Ocean. JLB Smith Institute of Ichthyology, Grahamstown

Guindon S, Gascuel O (2003) A simple, fast and accurate method to estimate large phylogenies by maximum likelihood. Syst Biol 52:696-704

Hasegawa M, Kishino H, Yano TA (1985) Dating of the human-ape splitting by a molecular clock of mitochondrial DNA. J Mol Evol 22:160-174

- Hyslop EJ (1980) Stomach content analysis, a review of methods and their application. J Fish Biol 17:411-430

Johnston TH (1937) Parasitic Nematoda. Australian Antarctic Expedition (1911-1914). Sci Rep Ser C 10:5-31

Johnston TH, Mawson PM (1945) Parasitic nematodes. BANZ-ARE (1929-1931). Ser B Zoology and Botany Vol 5. 5-74-159 Hassell Press, Adelaide

Kagei N, Asano K, Kihata M (1978) On the examination against parasites of Antarctic krill, Euphausia superba. Sci Rep Whales Res Inst Tokyo 30:311-313

- Kasamatsu F (2000) Species diversity of the whale community in the Antarctic. Mar Ecol Prog Ser 200:297-301

- Kellermanns E, Klimpel S, Palm HW (2007) Molecular identification of ascaridoid nematodes from the deep-sea onion- 
eye grenadier (Macrourus berglax) from the East Greenland Sea. Deep-Sea Res I 54:2194-2202

Klimpel S, Palm HW, Rückert S, Piatkowski U (2004) The life cycle of Anisakis simplex in the Norwegian Deep (northern North Sea). Parasitol Res 94:1-9

Klimpel S, Palm HW, Busch MW, Kellermanns E, Rückert S (2006) Fish parasites in the Arctic deep-sea: poor diversity in pelagic fish species vs. heavy parasite load in a demersal fish. Deep-Sea Res I 53:1167-1181

Klimpel S, Kellermanns E, Palm HW, Moravec F (2007) Zoogeography of fish parasites of the pearlside (Maurolicus muelleri), with genetic evidence of Anisakis simplex (s.s.) from the Mid-Atlantic Ridge. Mar Biol 152:725-732

Klimpel S, Palm HW, Busch MW, Kellermanns E (2008a) Fish parasites in the bathyal zone: the halosaur Halosauropsis macrochir (Günther, 1878) from the Mid-Atlantic Ridge. Deep-Sea Res II 55:229-235

Klimpel S, Kellermanns E, Palm HW (2008b) The role of pelagic swarm fish (Myctophidae: Teleostei) in the oceanic life cycle of Anisakis sibling species at the Mid-Atlantic Ridge, Central Atlantic. Parasitol Res 104:43-53

Klöser H, Plötz J (1992) Morphological distinction between adult Contracaecum radiatum and Contracaecum osculatum (Nematoda, Anisakidae) from the Weddell seal (Leptonychotes weddelli). Zool Scr 21:129-132

Klöser H, Plötz J, Palm HW, Bartsch A, Hubold G (1992) Adjustment of anisakid nematode life cycles to the high Antarctic food web as shown by Contracaecum radiatum and $C$. osculatum in the Weddell Sea. Antarct Sci 4:171-178

Leitner T, Foley B, Hahn B, Marx P, McCutchan F, Mellors J, Wolinsky S, Korber B (eds) (2005) HIV sequence compendium. LA-UR 06-0680. Theoretical Biology and Biophysics Group, Los Alamos National Laboratory, Los Alamos, NM

Linkowski TB (1985) Population biology of the myctophid fish Gymnoscopelus nicholsi (Gillbert, 1911) from the western South Atlantic. J Fish Biol 27:683-698

Mattiucci S, Nascetti G (2006) Molecular systematics, phylogeny and ecology of anisakid nematodes of the genus Anisakis Dujardin, 1845: an update. Parasite 13:99-113

Mattiucci S, Nascetti G (2007) Genetic diversity and infection levels of anisakid nematodes parasitic in fish and marine mammals from boreal and austral hemispheres. Vet Parasitol 148:43-57

Mattiucci S, Nascetti G (2008) Advances and trends in the molecular systematics of anisakid nematodes, with implications for their evolutionary ecology and host-parasite co-evolutionary processes. Adv Parasitol 66:47-148

Mattiucci S, Nascetti G, Cianchi R, Paggi L and others (1997) Genetic and ecological data on the Anisakis simplex complex with evidence for a new species (Nematoda, Ascaridoidea, Anisakidae). J Parasitol 83:401-416

May-Collado L, Agnarsson I (2006) Cytochrome b and Bayesian inference of whale phylogeny. Mol Phylogenet Evol 38:344-354

Mozgovoy AA (1953) Ascaridata of animals and man, and the diseases caused by them. Osnovy nematologii II. Izdatielstvo AN SSSR, Moskva (in Russian)

> Nikaido M, Matsuno F, Hamilton H, Brownell RL and others (2001) Retroposon analysis of major cetacean lineages: the monophyly of toothed whales and the paraphyly of river dolphins. Proc Natl Acad Sci USA 98:7384-7389

Nordøy ES, Folkow L, Blix AS (1995) Distribution and diving behaviour of crabeater seals (Lobodon carcinophagus) off Queen Maud Land. Polar Biol 15:261-268
Palm HW (1999) Ecology of Pseudoterranova decipiens (Krabbe, 1878) (Nematoda: Anisakidae) from Antarctic waters. Parasitol Res 85:638-646

Palm HW, Andersen K, Klöser H, Plötz J (1994) Occurrence of Pseudoterranova decipiens (Nematoda) in fish from the south-eastern Weddell Sea (Antarctic). Polar Biol 14: $539-544$

Palm HW, Reimann N, Spindler M, Plötz J (1998) The role of the rock cod Notothenia coriiceps in the life cycle of Antarctic parasites. Polar Biol 19:399-406

Palm HW, Klimpel S, Walter T (2007) Demersal fish parasite fauna around the South Shetland Islands: high species richness and low host specificity in Antarctic waters. Polar Biol 30:1513-1522

Pinkas L, Oliphant MS, Iverson ILK (1971) Food habits of albacore, bluefin tuna, and bonito in Californian waters. Calif Fish Game Fish Bull 152

Pusch C, Hulley PA, Kock KH (2004) Community structure and feeding ecology of mesopelagic fishes in the slope waters of King George Island (South Shetland Islands, Antarctica). Deep-Sea Res I 51:1685-1708

Rocka A (2004) Nematodes of the Antarctic fishes. Pol Polar Res 25:135-152

Rocka A (2006) Helminths of Antarctic fishes: life cycle biology, specificity and geographical distribution. Acta Parasitol 51:26-35

Rokicki J, Rodjuk G, Zdzitowiecki K, Laskowski Z (2009) Larval ascaridoid nematodes (Anisakidae) in fish from the South Shetland Islands (Southern Ocean). Pol Polar Res 30:49-58

Slade RW, Moritz C, Hoelzel AR, Burton HR (1998) Molecular population genetics of the southern elephant seal Mirounga leonina. Genetics 149:1945-1957

Thompson JD, Higgins DG, Gibson TJ (1994) CLUSTAL W: improving the sensitivity of progressive multiple sequence alignment through sequence weighting, positions-specific gap penalties and weight matrix choice. Nucleic Acids Res 22:4673-4680

Walter T, Palm HW, Piepiorka S, Rückert S (2002) Parasites of the Antarctic rattail Macrourus whitsoni (Regan, 1913) (Macrouridae, Gadiformes). Polar Biol 25:633-640

Williams R, Hedley SL, Hammond PS (2006) Modelling distribution and abundance of Antarctic baleen whales using ships of opportunity. Ecol Soc 11:1

Zdzitowiecki K (1991) Occurrence of digeneans in open sea fishes off the South Shetland Islands and South Georgia, and a list of fish digeneans in the Antarctic. Pol Polar Res 12:55-72

Zdzitowiecki K (1996) Acanthocephala in fish in the Weddell Sea (Antarctic). Acta Parasitol 41:199-203

Zdzitowiecki K (1997) Antarctic Digenea, parasites of fish. Koeltz Scientific Books, Königstein

Zdzitowiecki K, Laskowski Z (2004) Helminths of an Antarctic fish, Notothenia coriiceps, from the Vernadsky Station (Western Antarctica) in comparison with Admiralty Bay (South Shetland Islands). Helminthologica 41:201-207

> Zhu X, Gasser RB, Jacobs DE, Hung GC, Chilton NB (2000) Relationship among some ascaridoid nematodes based on ribosomal DNA sequence data. Parasitol Res 86:738-744

Zhu XQ, D'Amelio S, Palm HW, Paggi L, George-Nascimento M, Gasser RB (2002) SSCP-based identification of members within the Pseudoterranova decipiens complex (Nematoda: Ascaridoidea: Anisakidae) using genetic markers in the internal transcribed spacers of ribosomal DNA. Parasitology 124:615-623 
Appendix 1. Computed distance-matrix under Kimura-2-parameter substitution model among the 25 sequences of Anisakis spp. (24) and Hysterothylacium aduncum (1) for ITS-1/5.8S/ITS-2 sequences. Transition/transversion ratio = 2.0. Abbreviations as in Table 2

\begin{tabular}{|c|c|c|c|c|c|c|c|c|c|}
\hline & ApegMed & ApegJap & ApegChi & ApegAnt & AsimssBalt & AsimssSka & AsimssMAR & AsimssSpi & AsimssJap \\
\hline \multicolumn{10}{|l|}{ ApegMed } \\
\hline ApegJap & 0.002485 & & & & & & & & \\
\hline ApegChi & 0.002485 & 0.000000 & & & & & & & \\
\hline ApegAnt & 0.002485 & 0.000000 & 0.000000 & & & & & & \\
\hline AsimssBalt & 0.006224 & 0.003725 & 0.003725 & 0.003725 & & & & & \\
\hline AsimssSka & 0.007474 & 0.004970 & 0.004970 & 0.004970 & 0.001238 & & & & \\
\hline AsimssMAR & 0.006326 & 0.003786 & 0.003786 & 0.003786 & 0.002522 & 0.003786 & & & \\
\hline AsimssSpi & 0.006253 & 0.003742 & 0.003742 & 0.003742 & 0.002493 & 0.003742 & 0.002531 & & \\
\hline AsimssJap & 0.004976 & 0.002482 & 0.002482 & 0.002482 & 0.001240 & 0.002482 & 0.001260 & & \\
\hline AsimssNor & 0.004982 & 0.002485 & 0.002485 & 0.002485 & 0.001242 & 0.002485 & 0.001262 & & \\
\hline AsimssGS & 0.003742 & 0.001244 & 0.001244 & 0.001244 & 0.001244 & 0.001244 & 0.001264 & & \\
\hline AsimCCal & 0.007486 & 0.004978 & 0.004978 & 0.004978 & 0.006227 & 0.007477 & 0.006329 & 0.006255 & 0.004978 \\
\hline AsimCAnt2 & 0.009987 & 0.007471 & 0.007471 & 0.007471 & 0.008722 & 0.009975 & 0.008865 & 0.008761 & 0.007471 \\
\hline AsimCCan & 0.007480 & 0.004974 & 0.004974 & 0.004974 & 0.006222 & 0.007471 & 0.006323 & 0.006250 & 0.004974 \\
\hline AsimCAnt1 & 0.007480 & 0.004974 & 0.004974 & 0.004974 & 0.006222 & 0.007471 & 0.006323 & 0.006250 & 0.004974 \\
\hline AzipSA & 0.057420 & 0.054596 & 0.054596 & 0.054596 & 0.057343 & 0.055969 & 0.058355 & 0.057622 & 0.055969 \\
\hline AbrevFlo & 0.162265 & 0.158721 & 0.158721 & 0.158721 & 0.158721 & 0.160369 & 0.161930 & 0.156298 & 0.157077 \\
\hline AphyMed & 0.155447 & 0.151943 & 0.151943 & 0.151943 & 0.155212 & 0.156851 & 0.158339 & 0.152784 & 0.153576 \\
\hline ApagJap & 0.156201 & 0.152745 & 0.152745 & 0.152745 & 0.155737 & 0.157351 & 0.157261 & 0.153578 & 0.154356 \\
\hline AtypThai & 0.207940 & 0.204161 & 0.204161 & 0.204161 & 0.204161 & 0.202438 & 0.206351 & 0.205218 & 0.202438 \\
\hline AtypIndo2 & 0.207940 & 0.204161 & 0.204161 & 0.204161 & 0.204161 & 0.202438 & 0.206351 & 0.205218 & 0.202438 \\
\hline AtypIndo1 & 0.204479 & 0.200717 & 0.200717 & 0.200717 & 0.200717 & 0.199000 & 0.202840 & 0.201754 & 0.199000 \\
\hline AtypBra & 0.208154 & 0.204370 & 0.204370 & 0.204370 & 0.204370 & 0.202645 & 0.206566 & 0.205430 & 0.202645 \\
\hline AtypIndo & 0.208154 & 0.204370 & 0.204370 & 0.204370 & 0.204370 & 0.202645 & 0.206566 & 0.205430 & 0.202645 \\
\hline \multirow[t]{2}{*}{ HaduRef } & 0.601990 & 0.595596 & 0.595596 & 0.595596 & 0.602220 & 0.599616 & 0.593106 & 0.604085 & 0.600801 \\
\hline & AsimssNor & AsimssGS & AsimCCal & AsimCAnt2 & AsimCCan & AsimCAnt1 & AzipSA & AbrevFlo & \\
\hline AsimCCal & 0.004984 & 0.003743 & & & & & & & \\
\hline AsimCAnt2 & 0.007480 & 0.006242 & 0.001241 & & & & & & \\
\hline AsimCCan & 0.004980 & 0.003740 & 0.000000 & 0.002482 & & & & & \\
\hline AsimCAnt1 & 0.004980 & 0.003740 & 0.000000 & 0.002482 & 0.000000 & & & & \\
\hline AzipSA & 0.056043 & 0.054742 & 0.054598 & 0.055921 & 0.055921 & 0.055921 & & & \\
\hline AbrevFlo & 0.157315 & 0.157554 & 0.157232 & 0.158878 & 0.157232 & 0.157232 & 0.155848 & & \\
\hline AphyMed & 0.153808 & 0.154041 & 0.153727 & 0.155365 & 0.153727 & 0.153727 & 0.147671 & 0.049094 & \\
\hline ApagJap & 0.152972 & 0.154816 & 0.156120 & 0.157738 & 0.156120 & 0.156120 & 0.133256 & 0.062387 & \\
\hline AtypThai & 0.202752 & 0.201341 & 0.200716 & 0.202231 & 0.202231 & 0.202231 & 0.191710 & 0.212139 & \\
\hline AtypIndo2 & 0.202752 & 0.201341 & 0.200716 & 0.202231 & 0.202231 & 0.202231 & 0.191710 & 0.212139 & \\
\hline AtypIndo1 & 0.199309 & 0.197898 & 0.197284 & 0.198797 & 0.198797 & 0.198797 & 0.188262 & 0.208462 & \\
\hline AtypBra & 0.202960 & 0.201548 & 0.200921 & 0.202438 & 0.202438 & 0.202438 & 0.188069 & 0.210070 & \\
\hline AtypIndo & 0.202960 & 0.201548 & 0.200921 & 0.202438 & 0.202438 & 0.202438 & 0.188069 & 0.210070 & \\
\hline \multirow[t]{2}{*}{ HaduRef } & 0.598492 & 0.595190 & 0.605047 & 0.606932 & 0.606932 & 0.606932 & 0.576574 & 0.569163 & \\
\hline & AphyMed & ApagJap & AtypThai & AtypIndo2 & AtypIndo1 & AtypBra & AtypIndo & HaduRef & \\
\hline ApagJap & 0.069267 & & & & & & & & \\
\hline AtypThai & 0.228475 & 0.216129 & & & & & & & \\
\hline AtypIndo2 & 0.228475 & 0.216129 & 0.000000 & & & & & & \\
\hline AtypIndo1 & 0.224742 & 0.212515 & 0.002460 & 0.002460 & & & & & \\
\hline AtypBra & 0.226357 & 0.214091 & 0.004931 & 0.004931 & 0.002462 & & & & \\
\hline AtypIndo & 0.226357 & 0.214091 & 0.004968 & 0.004968 & 0.002481 & 0.000000 & & & \\
\hline HaduRef & 0.563021 & 0.573508 & 0.602925 & 0.602925 & 0.600224 & 0.598086 & 0.596720 & & \\
\hline
\end{tabular}

Editorial responsibility: Otto Kinne, Oldendorf/Luhe, Germany
Submitted: August 4, 2009; Accepted: January 19, 2010

Proofs received from author(s): March 4, 2010 